\title{
Golden mussel Limnoperna fortunei (Bivalvia: Mytilidae) distribution in the main hydrographical basins of Uruguay: update and predictions
}

\author{
ERNESTO BRUGNOLI ${ }^{1}$, JUAN CLEMENTE ${ }^{1}$, LUCÍA BOCCARDI ${ }^{1}$ \\ ANA BORTHAGARAY ${ }^{2}$ and FABRIZIO SCARABINO ${ }^{3}$ \\ ${ }^{1}$ Sección Limnología, Facultad de Ciencias, Universidad de la República Oriental del Uruguay \\ Iguá 4225, Montevideo, Uruguay \\ ${ }^{2}$ Sección Ecología, Facultad de Ciencias, Universidad de la República Oriental del Uruguay \\ Iguá 4225, Montevideo, Uruguay \\ ${ }^{3}$ Dirección Nacional de Recursos Acuáticos, Constituyente 1497, Montevideo, Uruguay \\ Manuscript received on July 28, 2004; accepted for publication on October 18, 2004; \\ presented by JosÉ G. TUNDISI
}

\begin{abstract}
Limnoperna fortunei, an Asiatic rivers bivalve has become a worldwide problematic invasive species causing several water quality and macrofouling problems. In the Neotropical region it was first recorded in 1991 in the Río de la Plata coast, Buenos Aires province. Since this, it showed a quick upstream invasion into the principals aquatic systems of the Plata Basin. Nevertheless, there is not a study about its invasion and distribution process in aquatic systems of Uruguay. We describe the new records of Limnoperna fortunei in Uruguayan coast of Río de la Plata, Santa Lucía, Negro and Uruguay Rivers. With these results we aim to estimate its distributional limits for Uruguay main hydrographical basins. We also deal with the role of salinity as the main abiotic factor in limiting the east distribution of this mussel in Uruguayan coast of Río de la Plata and as a potential determinant of the "new" colonization on the Atlantic and the Merín Lagoon Basins. Its presence in the ecosystems not only can cause changes at the ecosystem level but also endanger the associated community, favoring the displacement and the disappearance of endemic species.
\end{abstract}

Key words: invasive mollusk, biogeography, salinity, Uruguay.

\section{INTRODUCTION}

Limnoperna fortunei (Dunker 1857) is a mytilid invasive species of the Plata Basin, native from freshwater systems of China, Southeast Asia. It was introduced accidentally at the region in 1991 with ballast water (Darrigran and Pastorino 1995). It has an epifaunal and aggregate behavior (Cataldo and Boltovskoy 2000, Darrigran and Ezcurra de Drago 2000) and occurs in fresh and brackish water sys-

Correspondence to: Ernesto Brugnoli

E-mail: ebo@fcien.edu.uy tems, until salinity of 3 psu (Darrigran 2002). It is a dioeciously species with external fecundity and a swimming larvae phase (Darrigran and Pastorino 1993, Cataldo and Boltovskoy 2000) which makes it different from the native fresh-water bivalves of the neotropic region (Hyriidae, Mycetopodidae and Sphaeriidae) (Ezcurra de Drago personal communication). Since its arrival to the Plata Basin, this species had been found in several kinds of hard substrates, natural or artificial, showing an increase in its population abundance and changing the 
benthic community composition. It has also been reported as a new item in the diet of native fishes and caused problems of macrofouling in hydraulics installations (Darrigran et al. 1998, López-Armengol and Casciotta 1998, Darrigran and Ezcurra de Drago 2000, Montalto et al. 1999, Penchaszadeh et al. 2000, Clemente and Brugnoli 2002, Mansur et al. 2003)

The golden mussel was first found in South America in the coast of Río de la Plata, Buenos Aires province (Pastorino et al. 1993) and until now it had a quick spread upward the Plata Basin colonizing 1100 kilometers of its course (Darrigran 2002). Its occurrence has been reported in the main hydrologic systems of the region: coastal zones of Rio de la Plata (Scarabino and Verde 1995, Darrigran et al. 1998), Paraguay, Paraná, Salado and Uruguay Rivers (Darrigran and Ezcurra de Drago 2000, Darrigran 2002) and Los Patos Lagoon (Mansur et al. 1999, 2003).

In Uruguay it has been registered in four of the six main hydrographical basins: Río de la Plata, Santa Lucía, Negro and Uruguay Rivers (Scarabino and Verde 1995, Darrigran and Ezcurra de Drago 2000, Clemente and Brugnoli 2002, Leites and Bellagamba 2002, Ezcurra de Drago et al. unpublished data). In the Merín Lagoon and Atlantic Basins, there have not been records of this mussel, although Brugnoli et al. (2003), suggests that its access to both basins could had been possible throughout the San Gonzalo channel which connects Los Patos and Merín Lagoon systems.

Despite of its invasion process, the risk for the autochthonous biodiversity (Orensanz et al. 2002, Brugnoli et al. 2003, Scarabino 2004) and the macrofouling problems (Brugnoli and Clemente 2002, Clemente and Brugnoli 2002) there are few studies about this mussel in Uruguay (Scarabino and Verde 1995, Gorga and Clemente 2000, Leites and Bellagamba 2002, Conde et al. 2002, Clemente and Brugnoli 2002, Brugnoli et al. 2003, Ezcurra de Drago et al. unpublished data). Moreover, these works are isolated, do not have a temporal continuity and there are not available to the international scientific community.

This work aimed an update of the information about the presence of Limnoperna fortunei, study its negative effects on the biodiversity and predict its distribution over the hydrographical basins of Uruguay, to establish a base line for future research.

\section{MATERIALS AND METHODS}

\section{StUdy AreA}

Uruguay has a large network of rivers grouped in six main basins (Río de la Plata, Santa Lucía, Negro and Uruguay Rivers, Merín Lagoon and Atlantic Ocean) with different extension and aquatic ecosystems (Table I).

The bibliographic search to construct a distribution map of Limnoperna fortunei included technical reports and scientific papers (Table II). The benthic organisms (adults and juveniles) were collected manually in different environments (Table II), fixed with alcohol $70 \%$ and deposited in the Museo Nacional de Historia Natural y Antropología (Montevideo) (MHNM no. sample). Mollusk larvae were collected with zooplankton net $(68 \mu \mathrm{m})$ between November 2000 and January 2002 in Palmar Reservoir and Yí River (see Conde et al. 2002), fixed with formalin $4 \%$ and then with alcohol $60 \%$ (Ezcurra de Drago personal communication).

\section{PREDICTIONS}

Guidelines for identifying potential aquatic invaders of Ricciardi and Rasmussen (1998) were used to predict the biogeographic distribution of the golden mussel in the Uruguay basins. These authors suggest three steps toward predicting invasions:

- Identify potential donor regions and dispersal pathways of future invaders (e.g.: lower and intermediate basins of the different hydrographical basins and Los Patos Lagoon).

- Select potential invaders using biological criteria (e.g.: Limnoperna fortunei).

- Use invasion history as a predictive criterion. (e.g.: upstream invasion). 
TABLE I

Main characteristics of the Uruguayan hydrographical basins.

\begin{tabular}{c|c|c|c|c|c|c}
\hline $\begin{array}{c}\text { Hydrographical } \\
\text { basin }\end{array}$ & $\begin{array}{c}\text { Río de la } \\
\text { Plata }\end{array}$ & $\begin{array}{c}\text { Santa Lucía } \\
\text { River }\end{array}$ & $\begin{array}{c}\text { Negro } \\
\text { River }\end{array}$ & $\begin{array}{c}\text { Uruguay } \\
\text { River }\end{array}$ & $\begin{array}{c}\text { Merín } \\
\text { Lagoon }\end{array}$ & Atlantic \\
\hline $\begin{array}{c}\text { Total area } \\
\left(\mathrm{km}^{2}\right)^{*}\end{array}$ & 12.780 & 13.310 & 68.140 & 45.860 & 28.950 & 8.480 \\
\hline $\begin{array}{c}\text { Extension } \\
\text { main river }(\mathrm{km})\end{array}$ & 370 & 230 & 800 & 1.800 & $3.749^{* *}$ & - \\
\hline $\begin{array}{c}\text { Principal } \\
\text { aquatic } \\
\text { ecosystems }\end{array}$ & $\begin{array}{c}\text { Rivers and } \\
\text { streams }\end{array}$ & $\begin{array}{c}\text { Rivers, } \\
\text { streams and } \\
\text { reservoirs }\end{array}$ & $\begin{array}{c}\text { Rivers, } \\
\text { reservoirs } \\
\text { and streams }\end{array}$ & $\begin{array}{c}\text { Rivers, } \\
\text { streams and } \\
\text { reservoir }\end{array}$ & $\begin{array}{c}\text { Rivers, } \\
\text { wetlands, } \\
\text { reservoirs } \\
\text { and streams }\end{array}$ & $\begin{array}{c}\text { Coastal } \\
\text { lagoons } \\
\text { wetlands } \\
\text { and streams }\end{array}$ \\
\hline
\end{tabular}

*Only the surface in Uruguay; ${ }^{* *} \mathrm{~km}^{2}$.

\section{TABLE II}

Kind of reports and samples used to construct the biologic-distributional map of Limnoperna fortunei in the Uruguayan hydrographical basins.

\begin{tabular}{c|c|l}
\hline Basin & Adult/Larvae & $\begin{array}{l}\text { Technician (T), Sample (S) or } \\
\text { Scientific information }\end{array}$ \\
\hline Río de la Plata & Adult & $\begin{array}{l}\text { DNH* (T,S), DINARA** (T,S), Scarabino and }_{\text {Verde (1995), Giménez (unpublished data), }} \\
\text { References this article. }\end{array}$ \\
\hline Santa Lucía & Adult & DINARA (T,S). \\
\hline Negro & Adult/Larva & $\begin{array}{l}\text { UTE*** (T,S), Clemente and Brugnoli (2002), } \\
\text { Conde et al. (2002), Brugnoli (unpublished data) (S). }\end{array}$ \\
\hline Uruguay & Adult/Larva & $\begin{array}{l}\text { DINARA (T,S), Darrigran and Ezcurra de Drago (2000), } \\
\text { Leites and Bellagamba (2002), Irurueta et al. (2003). }\end{array}$ \\
\hline Merín and Atlantic & No & \\
\hline
\end{tabular}

*DNH, Dirección Nacional de Hidrografía; **DINARA, Dirección Nacional de Recursos Acuáticos,

*** UTE Usinas Termoeléctricas del Estado. 
The potential effect of the invasion process in relation to the biodiversity of the aquatic ecosystems were analyzed using bibliography of the region (Conde et al. 2002, Scarabino 2004) and unpublished data of the first author.

\section{RESULTS AND DISCUSSION}

\section{Previous Temporal Registers and Predictions}

Limnoperna fortune $i$ was first recorded for Uruguay in Río de la Plata Basin in September 1994 in the Artilleros and Barrancas of San Pedro (Colonia, Uruguay) and some months later it was collected in the Pascual and Arazatí beaches (San José, Uruguay) (Scarabino and Verde 1995). Then Ituarte (1997) reported juvenile organism in soft substrates in San José and Colonia departments. Between 1999 and 2000, Cataldo et al. (2002) found the golden mussel in the stomach contain of diverse native fishes in the inner zone of Río de la Plata. In 2001, adults organisms settlements were reported in the metallic contention structures in the Higueritas harbor (Colonia) (MHNM no. 15.205). During 2002 several samplings were sampled in the river coast (Colonia del Sacramento and Rosario, Colonia; Punta Espinillo, Montevideo) and L. fortunei was collected settled in hard substrates (Giménez unpublished data). The salinity of Colonia and Montevideo localities were 0 and 1.6 respectively.

The actual observed distribution along the Uruguayan coast in the Río de la Plata (Fig. 1), suggests that $L$. fortune $i$ would present its east limit of distribution nearby Punta Espinillo, where the isohaline 2-3 is localized according to Nagy et al. (1997). In addition, Darrigran and Pastorino (1995) suggested the distribution patterns of golden mussel in Argentinean coastal zone of Río de la Plata is limited by high salinities and the saline tolerance limit of the golden mussel is 3 according to Darrigan (2002). Besides this, Maytía and Scarabino (1979) suggest that the salinity gradient generated by the interaction of Río de la Plata and the Atlantic Ocean is the main factor determining the spatial patterns of distribution and composition of species harbored in hard substrates. The east distributional limit of $L$. fortunei would have eastward or westward oscillations associated with its life history traits (complex life cycle, high dispersion and settlement capacity) and the dominant environmental conditions of the area (temperature and salinity).

In the Santa Lucía River Basin L. fortunei has been first reported in 1996 in the Colorado stream (MHNM no. 15.200). Then, Ezcurra de Drago et al. (unpublished data), found it in the Santa Lucía River main course. Between 2000 and 2003 L. fortunei was registered in different localities (Fig. 1): Paso Belastiquí (2000), Aguas Corrientes (2000), Rincón de Vignoli (2002) and Paso Severino Reservoir (2003) (MHNM no. 15.202, 203, 206, 210). The occurrence of adults and juvenile organisms in aquatic systems used for human consumption or industrial use (Aguas Corrientes and Paso Severino Reservoir) should be considering as an alert of macrofouling problems which can affect the hydraulics installations situated in this basin. Furthermore, that recently reports (2002-2003) in the upper part of this basin suggested a progress of this invasive species in a short time-period.

In the Negro River Basin L. fortunei was recorded in 1999 for the first time in the cooling water system of Palmar dam (Gorga and Clemente 2000, Clemente and Brugnoli 2002) (MHNM no. 15.201). Conde et al. (2002) registered the presence of larvae of bivalves in zooplanktonic samples in the Palmar Reservoir and Yí River with spatial-temporal changes in their abundance (Fig. 2). During January 2002, in Yí River and the littoral zone of the Palmar Reservoir adult specimens of golden mussel were found settled in tree's branches and in hard substrate (MHNM no. 15.207, 208). In December 2002 benthic organisms of Limnoperna fortunei were also collected in the installations of Baygorria dam (MHNM no. 15.209) (Fig. 1).

These results confirm Conde et al. (2002) suggestions about the increased of the geographic range of distribution of L. fortunei in Negro River basin. Its extensive distribution not only means a potential ecological problem but also an economic 


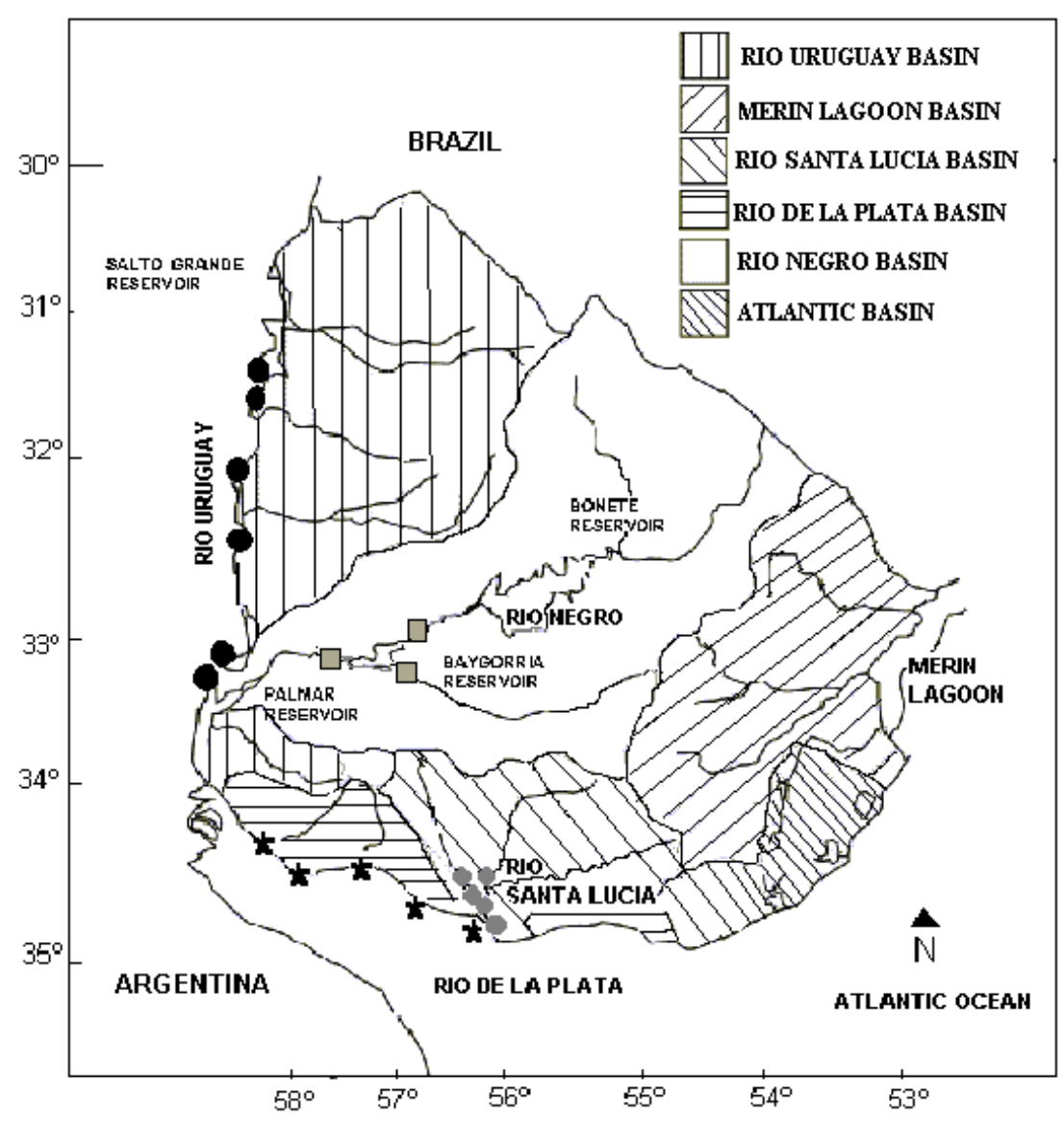

Fig. 1 - Distribution of golden mussel (Limnoperna fortunei) to 2003 in the main Uruguayan hydrographical basins (Map from Conde and Sommaruga 1999). Río de la Plata (*), Santa Lucía ( o ), Negro ( $\square$ ) and Uruguay Rivers (• ).

risk for the dams and the hydraulic installations situated upstream Palmar (i.e. Baygorria and Rincón del Bonete dams).

Until now, there are not any reports about the presence of these organisms in the upper part of the Negro River Basin (Mansur personal communication). However, according to the dispersal upstream behavior found of Limnoperna fortunei in Neotropical region (Darrigran 2002), we expect to see an increase of its geographical distribution towards that area for the next years.

In the case of Uruguay River Basin, recently in 2000 the first record about the presence of larvae or adults was made, occurring nearby the Colón (Concepción del Uruguay) (Darrigran and Ezcurra de Drago 2000). For the Uruguay River itself the golden mussel was first recorded in ben- thic communities, in Las Cañas (2000) (south of the Fray Bentos city, Uruguay) (MHNM no. 15.204) and Gualeguaychú River (Argentina) (Ezcurra de Drago et al. unpublished data). In March 2001, this species was collected in Gualeguaychú (larvae and adults) and in Concepción del Uruguay (only larvae) (Ezcurra de Drago et al. unpublished data). Leites and Bellagamba (2002) found adults organisms in the Salto Grande Reservoir included in the stomach contain of the "armado común" (Pterodoras granulosus). Recently, Irurueta et al. (2003) found benthic individuals in the hydraulic installations of a meat packing plant of Paysandú (Uruguay) and described the larvae cycle of golden mussel in Las Cañas.

Our results showed that in the Uruguay River Basin, until 2003 L. fortunei was distributed in the 
lower and intermediate part of the river, being the Salto Grande Reservoir its north distribution limit (Fig. 1). Since 2003 a new stage in the invasion process seems to be started in the hydrographic systems situated northward the Salto Grande Reservoir, affecting the upper part of the Uruguay River. This new invasion process would being facilitated by the hard substrate that dominates the bed and littoral zone of the river (Di Persia and Neiff 1986).

There are no reports about the presence of the golden mussel in the Merín Lagoon and the Atlantic Ocean Basins. Los Patos $\left(10360 \mathrm{~km}^{2}\right)$ and the Merín Lagoons $\left(3749 \mathrm{~km}^{2}\right)$ are communicated by the San Gonzalo $(70 \mathrm{~km})$ channel which discharges in the estuarine region of Los Patos Lagoon, in the southern part of the Merín-Patos system (Niencheski et al. 1999). In the north zone of Los Patos Lagoon is localized the Guaíba Lake Basin (Brasil) where Limnoperna fortunei invasion was registered in 1998 (Mansur et al. 1999). Mansur et al. (2003) reported the presence of this species in the central and south zone of this lagoon (Arambaré in 2000 and mouth of San Lorenzo River in 2001). We expect to find the golden mussel in Merín and Atlantic Basin in a few years as a result of its dispersion from Los Patos Lagoon throughout the San Gonzalo channel (Brugnoli et al. 2003).

In the estuarine zone of Los Patos Lagoon, the main conditioning factors of its vertical salinity distribution are the local meteorological conditions (precipitation and winds) (Moller and Casting 1999, Niencheski et al. 1999) and the input of fresh water from the most important tributaries of the upper zone (Niencheski et al. 1999). During the later winter and beginning of spring and as a result of increasing discharges of the affluent rivers, the estuarine region of the Los Patos Lagoon change to a freshwater condition (Niencheski et al. 1999) with a circulation controlled by its discharges (Moller and Casting 1999). Moreover, according to the longitudinal distribution of salinity observed nearby the San Gonzalo channel (Moller and Casting 1999), this zone present tolerable conditions for the occurrence of L. fortunei.
Santos and Mansur (2002) suggested that golden mussel populations in the Gauíba lake have the ability of reproducing during the all year with a peak-increase in spring. During this months the environmental conditions were favorable, (patterns of circulation and salinity) for a passive larvae dispersion from Los Patos to Merín Lagoon through the San Gonzalo channel. This larvae has the capacity of entering in the Merín Lagoon counter current in a similar manner to that one observed in the already invaded aquatic systems and the behavior dispersal observed for Limnoperna fortunei in Neotropical region (Darrigran 2002). Finally, after the larvae settlement in Merín Lagoon, the golden mussel would probably be dispersed by different vectors (ships or birds) to other aquatic ecosystems in the Atlantic Ocean and the Merín Lagoon Basins. According to Mansur and Garces (1988), the ingress of the bivalve Corbicula fluminea in the Laguna Merín could have occurred by larvae transport from Uruguay rivers or throughout the San Gonzalo channel, from Los Patos Lagoon.

\section{NuISANCE EFFECTS ON BIODIVERSITY}

\section{Benthic communities}

Scarabino (2004) reported the potential impact of Limnoperna fortunei on the Uruguayan native freshwater malacofauna, with special reference to endemics. In this setting, the infaunal macrobivalves composed by Etherioidea (Castalia, Diplodon, Mycetopoda, Monocondylaea, Fossula, Anodontites, Leila) and Corbiculidae (Cyanocyclas), may be dramatically affected (Orensanz et al. 2002, Mansur et al. 2003, Scarabino 2004).

Limnoperna fortunei may also have negative effects on the hard bottom epifauna, which contains elements with high levels of endemism in the region. Martin and Darrigran (1994) and Darrigran et al. (1998) documented changes in the communities inhabiting that fauna in the Argentinean coast of the Río de la Plata estuary, which implies increasing of the specific richness and abundance of Hirudinea and Oligochaeta, and decreasing of those param- 
eters for Gastropoda. Scarabino (2004) discussed the potential impact on the gastropods Potamolithus, Pomella, Felipponea, Chilina and Ancylidae and the bivalve genus Eupera. Like these, other benthic invertebrates typically belonging to the Uruguay River fauna, may also be impacted, such as the remarkable fauna of Porifera, bryozoans (Hislopia, Fredericella, Plumatella), kamptozoans (Urnatella), and diverse entomofauna composed by Plecoptera, Neuroptera, Ephemeroptera and Trichoptera (see Di Persia and Olazarri 1986).

The impact history of a species is a valuable guide for predicting the consequences of its introduction into a new environment (Ricciardi 2003), however the variety of reactions to the $L$. fortune $i$ invasion is difficult to predict in view of the poor knowledge of the local fauna and ecological processes. In this sense, comparing results with other geographic areas and invasive bivalves such as Dreissena spp., must be done with extreme care. However, information of this kind (Ricciardi et al. 1997, Darrigran et al. 1998) support the concept that in freshwater ecosystems the colonization of invasive epibenthic bivalves favors the presence of Chironomidae dipterans, Hirudinea and Oligochaeta.

\section{Planktonic communities}

The abundance of bivalve larvae found in the Negro River presented spatial-temporal variations. The minimum values were found during September in Palmar (3 ind. $\left./ \mathrm{m}^{3}\right)$ and Yí stations $\left(0\right.$ ind. $\left./ \mathrm{m}^{3}\right)$, and the maximum was found in December in Yí (8610 ind. $/ \mathrm{m}^{3}$ ) (Fig. 2). According to Darrigran et al. (1999) Limnoperna fortunei has continuous reproduction having a strong relation between its maximum activity and temperature changes. Besides that, the abundance increase of the golden mussel larvae in Yí station, could be associated with the settlement of benthic organisms in the area (Conde et al. 2002).

In the Yí station the relative abundance of the main groups of zooplankton changed due to the presence of this mollusk larvae. It could be related with
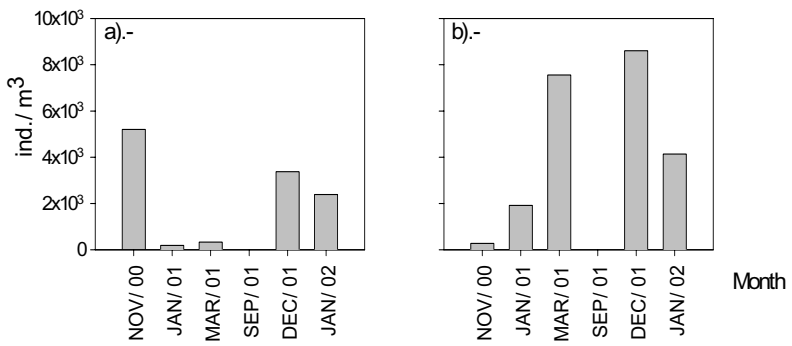

Fig. 2 - Mollusk larvae abundance $\left(\mathrm{ind} / \mathrm{m}^{3}\right.$ ) variation in Palmar (a) and Yí (b) stations. Palmar Reservoir, 2000-2002.

an increase of it abundance, from $0.4 \%$ in November 2000 to $77 \%$ in January 2002 (Fig. 3). This caused changes in the relative abundances of the main groups of the zooplankton (Crustacea and Rotifera) and could cause potential modifications in the trophic web. On the other hand, Conde et al. (2002) suggested that the lower chlorophyll a concentration and the relative low zooplankton abundance could be associated with the presence of benthic adults in Palmar and Yí stations. Several studies showed a negative relation between the presence of benthic invasive organisms and both the concentration of the chlorophyll a and the relative zooplankton abundance, due to the higher filtration rate of the invasive organisms (MacIsaac et al. 1995, Pace et al. 1998).

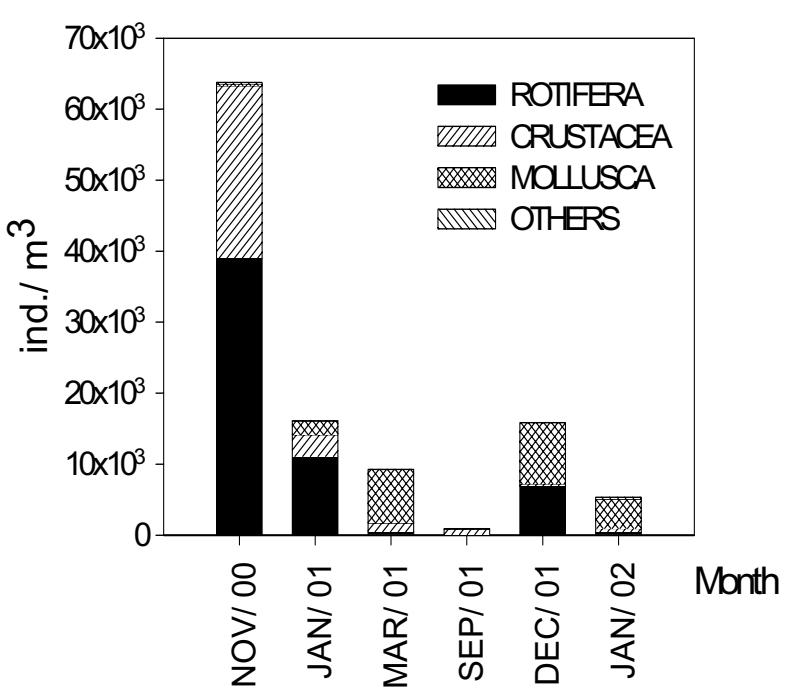

Fig. 3 - Abundance (ind $/ \mathrm{m}^{3}$ ) variation of zooplankton groups in Yí station. Palmar Reservoir, 2000-2002. 


\section{FINAL REMARKS}

The results showed in this work, the multiple and diverse recent reports (most of them unpublished) allowed us to describe the biogeography distribution of Limnoperna fortunei in Uruguay showing its increased distribution along Santa Lucía, Negro and Uruguay Rivers Basins. In this context, we will expect for the next years that its invasion process continue affecting the upper portion of these basins.

Concerning to the Uruguayan coast in Río de la Plata, the golden mussel would probably present its distribution limit associated with their salinity tolerance in Punta Espinillo. Although there are not reports of the presence of this specie in the Atlantic basin or Merín Lagoon Basin, we suppose that its invasion in both basins could be possible throughout the San Gonzalo channel from Los Patos Lagoon.

According to its dispersion rate and new habitat colonization, the negative effects will be related with the biodiversity and the human utility of hydraulic installations. The expected ecological negative effects will be mainly over the biodiversity of native species with endemic characteristics (clams Unionida and several gastropod taxa), also causing changes in the trophic webs due to modifications in planktonic communities. To avoid the mussel potential impacts and the negative effects over the biodiversity and hydraulic installations, it will be necessary the developing of basic research to identify the weakness traits of this species cycle and implement environmental friendly population management strategies.

\section{ACKNOWLEDGMENTS}

The authors thank J.G. Tundisi for the presentation, I. Ezcurra de Drago, M.C.D. Mansur for their cooperation and P. Muniz and C. Kruk for the suggestions and English translations of P. Muníz and K. Kruk; Leticia Burone for the Portuguese translation. The samples in different Uruguayan basins were facilitate by UTE (Gerencia de Generación Hidráulica), Dirección Nacional de Hidrografía and ANCAP (División de Medio Ambiente Seguridad Industrial y Gestión de Calidad).

\section{RESUMO}

Limnoperna fortunei, é um bivalve invasor de origem asiática que ocasiona problemas na qualidade d'água e poluição em diversas parte do mundo. Na região Neotropical foi registrado pela primeira vez na costa do Rio de la Plata, província de Buenos Aires. Desde então mostrou uma rápida invasão águas acima nos principais sistemas aquáticos da Bacia del Plata. Porém, ainda não existem estudos acerca do processo de invasão e distribuição nos ecossistemas aquáticos do Uruguai. O presente trabalho descreve os novos registros de Limnoperna fortunei na costa uruguaia do Rio de la Plata e dos Rios Santa Lucia e Uruguai. Os presentes resultados permitem avaliar seus limites de distribuição nas principais bacias hidrográficas do Uruguai. Discute-se o papel da salinidade como o principal fator abiótico limitante da distribuição deste mexilhão dourado na costa Uruguaia do Rio de la Plata e como potencial determinante na nova colonização nas bacias hidrográficas das Lagoas Merin e Atlântica. Sua presença nos ecossistemas aquáticos pode ocasionar não apenas mudanças a nível do ecossistema, mas também pôr em perigo as comunidades associadas favorecendo o desaparecimento das espécies endêmicas.

Palavras-chave: molusco invasor, biogeografia, salinidade, Uruguai.

\section{REFERENCES}

Brugnoli E and Clemente J. 2002. Los moluscos invasores en la Cuenca del Plata: su potencial impacto ambiental y económico. Revista AMBIOS Marzo, p. 27-30.

Brugnoli E, Clemente J, Boccardi L, Borthagaray A And Scarabino F. 2003. Distribución del mejillón dorado (Limnoperna fortunei) en las cuencas hidrográficas de Uruguay: situación actual y predicciones. In: Actas VII JoRnadas de Zoología y I ENCUENTro de Ecología Uruguay, Montevideo, Uruguay, $110 \mathrm{p}$.

Cataldo D and Boltovskoy D. 2000. Yearly reproductive activity of Limnoperna fortunei, as inferred from the occurrence of its larvae in the plankton of the lower Paraná river and the Río de la Plata estuary (Argentina). Aquat Ecol 34: 307-317.

Cataldo D, Boltovskoy D, Marini V and Correa N. 2002. Limitantes de Limnoperna fortunei en la cuenca del Plata: predación por peces. In TercerA 
JORNADA SOBRE CONSERVACIÓN DE LA FAUnA ÍCTICA en el Río Uruguay, Caru, Paysandú, Uruguay, p. 1-5.

Clemente J and Brugnoli E. 2002. First record of Limnoperna fortunei (Dunker 1857) (Bivalvia: Mytilidae) in continental waters of Uruguay (Río Negro and Río Yí Rivers). Bol Soc Zool Uruguay 13: 29-33.

Conde D and Sommaruga R. 1999. A review of the state of Limnology in Uruguay. In: WeTZEL AND Gopal (Eds.), Limnology in developing countries 2, New Delhi, International Scientific Publications/SIL, p. 1-31.

Conde D, Paradiso M, Gorga J, Brugnoli E, De León L AND Mandiá M. 2002. Problemática de la calidad de agua en el sistema de grandes embalses del Río Negro (Uruguay). Revista CIER 39: 51-68.

DARrigran G. 2002. Potential impact of filterfeeding invaders on temperate inland freshwater environments. Biol Inv 4: 145-156.

Darrigran G and Ezcurra de Drago I. 2000. Invasion of the exotic freshwater mussel Limnoperna fortunei (Dunker 1857) (Bivalvia: Mytilidae) in South America. The Nautilus 114: 69-73.

Darrigran G and Pastorino G. 1993. Bivalvos invasores en el Río de la Plata, Argentina. Com Soc Malac 64-65: 309-313.

DARrigran G AND PASTORINo G. 1995. The recent introduction of a freshwater asiatic bivalve, Limnoperna fortunei (Mytilidae) into South America. The Veliger 38: 171-175.

Darrigran G, Martín SM, Gullo B and ArmenDÁRIZ L. 1998. Macroinvertebrates associated with Limnoperna fortunei (Dunker 1857) (Bivalvia: Mytilidae) in Río de la Plata, Argentina. Hydrobiol 367: 223-230.

Darrigran G, Penchaszadeh P and Damborenea MC. 1999. The life cycle of Limnoperna fortunei (Dunker 1857) (Bivalvia: Mytilidae) from a neotropical temperate locality. J Shellf Res 18: 361-365.

Di Persia DH and NeIfF JJ. 1986. The Uruguay River System. In: Davies AND WALKer (Eds.), The Ecology of River Systems, Dordrecht, The Netherlands, Junks Publishers, p. 559-621.

Di Persia DH and Olazarri J. 1986. Zoobenthos of the Uruguay system. In: DAVIES AND WALKER
(Eds.), The Ecology of River Systems, Dordrecht, The Netherlands, Junks Publishers, p. 623-629.

Gorga J And Clemente J. 2000. Primera aproximación al problema del biofouling en la Represa Palmar. Sec. Limnología, Facultad de Ciencias, UTE, 18 p.

Irurueta M, DAmborenea C AND DARrigran G. 2003. Variación de la densidad larvaria del mejillón dorado (Limnopernafortunei) (Bivalvia: Mytilidae) en el Río Uruguay, balneario Las Cañas. In: ACTAS VII JoRNADAS DE ZoOlOGÍA Y I ENCUENTRO DE ECOLOGÍA Uruguay, Montevideo, Uruguay, $117 \mathrm{p}$.

ITUARTE CF. 1997. Limnoperna fortunei (Dunker 1857) (Bivalvia: Mytilidae) en la costa uruguaya del Río de la Plata. Neotrópica 43: 117-118.

Leites V and Bellagamba M. 2002. Comunicación preliminar de la presencia de Limnoperna fortunei en armado común (Pterodoras granulosus) (Piscies, Doradidae) en la Represa de Salto Grande. Comisión Administradora del Río Uruguay. In Tercera JorNADA SOBRE CONSERVACIÓN DE LA FAUNA ICTICA EN el Río Uruguay, Caru, Paysandú, Uruguay.

López-Armengol MF and Casciotta J. 1998. First record of the predation of the introduced freshwater bivalve Limnoperna fortunei (Mytilidae) by the native fish Micropogonias (Scianidae) in the Río de la Plata estuary, South America. Iberus, 105-108.

MacIsaAC H, LonneE CH ANd LeaCh J. 1995. Suppression of microzooplancton by zebra mussels: importance of mussel size. Freshw Biol 34: 379-387.

Mansur MC and Garces PMM. 1988. Ocorrência e densidade de Corbicula fluminea (Muller 1774) e Neocorbicula limosa (Maton 1811) na Estação Ecológica do Taim e áreas adjacentes. Río Grande do Sul, Brasil (Mollusca, Bivalvia, Corbiculidae). Iheringia ser Zol 68: 99-115.

Mansur MC, Valer RM And Aires N. 1999. Limnoperna fortunei (Dunker 1857) molusco bivalve invasor na bacia do Guaíba, Río Grande do Sul, Brasil. Biociencias, Porto Alegre 7: 147-149.

Mansur MC, Pinhiero dos Santos C, Darrigran G, Hydrich I, Calli C And Rossoni Cardoso F. 2003. Primeros dados quali-quantitativos do mexilhãodourado, Limnoperna fortunei (Dunker), no Delta do Jacuí, no Lago Gauíba e na Laguna dos Patos, Río Grande do Sul, Brasil e alguns aspectos de sua invasão no novo ambiente. Rev Brasil Zool 20: 75-84. 
MARTIN SM AND DARRIGRAN G. 1994. Limnoperna fortunei (Dunker 1857) en el balneario Bagliardi, Río de la Plata. Alteración en la composición de la malacofauna litoral. Tankay 1: 161-166.

Maytía S ANd Scarabino V. 1979. Las comunidades del litoral rocoso del Uruguay: zonación, distribución local y consideraciones biogeográficas. In: Memorias del Seminario sobre Ecología BenTónica Y SEDIMENTACión DE LA Plataforma Atlántico Sur, UNESCO, p. 149-160.

Moller OO And Casting P. 1999. Hydrographical Characteristics of the Estuarine Area of Patos Lagoon $\left(30^{\circ} \mathrm{S}\right.$, Brazil). In: Perillo, Piccolo AND PINo-Quivira (Eds.), Estuaries of South America. Their Geomorphology and Dynamics, SpringerVerlag, p. 83-100.

Montalto L, Oliveros O, Ezcurra de Drago I and Denonte L. 1999. Peces del río Paraná medio, predadores de una especie invasora Limnoperna fortunei (Bivalvia: Mytilidae). Revista FABICIB 3: 85-101.

Nagy G, Martínez C, Caffera R, Pedrosa G, Forbes E, Perdomo A and López Laborde J. 1997. The hydrological and climatic setting of the Río de la Plata. In: Wells And Daborn (Eds.), The Rio de la Plata. An environmental overview. An EcoPlata Project Background Report, Dalhousie University, Halifax, Nova Scotia, p. 17-68.

Niencheski LF, Baumgarten MA DA GRA, Fillmann G AND Windom HL. 1999. Nutrients and Suspend matter behaviour in the Patos Lagoon Estuary (Brazil). In: Perillo, Piccolo And Pino-Quivira (Eds.), Estuaries of South America. Their Geomorphology and Dynamics, Springer-Verlag, p. 67-81.

Orensanz JM, Bortolus A, Casas G, Darrigran G, Elías R, López-Gappa JJ, Obenat S, Pascual M, Pastorino G, Penchaszdeh P, Piriz ML, ScaraBINo F, Schwindt E, SPIVAK ED and Villarino EA. 2002. No longer the pristines confines of the World ocean: a survey of exotic marine species in the southwestern Atlantic. Biol Inv 4: 115-143.
Pace M, Findlay S AND Fischer D. 1998. Effects of an invasive bivalve on the zooplankton community of the Hudson River. Freshw Biol 39: 103-116.

Pastorino G, Darrigran G, Martin S ANd Lunaschi G. 1993. Limnoperna fortunei (Dunker 1857) (Mytilidae), nuevo bivalvo invasor en aguas del Río de la Plata. Neotrópica 39: 34.

Penchaszadeh P, Darrigran G, Angulo C, Averbuj A, Brigger M, Dogliotti A and Pirez N. 2000. Predation of the invasive freshwater mussel Limnoperna fortunei (Dunker 1857) (Mytilidae) by the fish Leporinus obtusidens (Valenciennes, 1846) (Anastomidae) in the Río de la Plata, Argentina. J Shellf Res 19: 229-231.

RicCIARDi A. 2003. Predicting the impacts of an introduced species from its invasion history: an empirical approach applied to zebra mussel invasion. Freshw Biol 48: 972-981.

Ricciardi A And Rasmussen JB. 1998. Predicting the identity and impact of future biological invaders: a priority for aquatic resource management. Can J Fish Aquat Sci 55: 1759-1765.

RicCIARdi A, WhORISKEy FG AND RASMUSSEN JB. 1997. The role of the zebra mussel (Dreissena polymorpha) instructuring macroinvertebrate communities on hard substrata. Can J Fish Aquat Sci 54: 2596-2608.

Santos CP AND Mansur MC. 2002. Primeros dados sobre o assentamiento de pós-larvas do bivalve invasor Limnoperna fortunei (Dunker 1857) (Bivalvia: Mytilidae), na Bacia do Guaiba, Rio Grande do Sul, Brasil. In: Programa de Resúmenes y Anales del V Congreso LatinOAMERICANO DE MALACOLOGÍA, São Paulo, Brasil, 78a p.

Scarabino F. 2004. Conservación de la malacofauna uruguaya. Com Soc Malac Uruguay 8 (82/83): 267-273.

SCARABINo F AND Verde M. 1995. Limnoperna fortunei (Dunker 1857) en la costa uruguaya del Río de la Plata (Bivalvia: Mytilidae). Com Soc Malac Uruguay 7: 374-375. 